\title{
On the C-E Translation of Chinese Small and Medium Sized Clothing Corporate Profiles From the Perspective of Skopos Theory
}

\begin{abstract}
WANG Yin
Ningbo Dahongying University, Ningbo, China

Company profile is the window of enterprises to propagandize their spirits and cultures, and cooperation profile translation is the convenient and effective way for companies to enter in the international market better. Based on a critical analysis of translation problems arising in small and medium sized apparel company profiles in China conducted under the framework of Skopos Theory, some corresponding practical translation strategies are provided, such as deletion, addition, and so on. The author expects this thesis could offer reliability techniques and improve the quality of Chinese small and medium sized apparel company profiles.
\end{abstract}

Keywords: Skopos Theory, Chinese small and medium sized clothing company profiles, translation

\section{Introduction}

Apparel industry has been one of the dominant industries in China. In recent years, the development of apparel industry has attracted more and more people's attention. In addition to building a trusted brand, many domestic clothing enterprises have been fully aware of the importance of having a good enterprise profile for sustainable development and internationalization of an enterprise. Therefore, plenty of apparel companies have their company profiles translated into English. However, the quality of the English versions is not satisfactory, which not only affects images of the company but also obstacles communication between the company and its foreign customers so as to block the development of trade.

\section{The Interpretation of Skopos Theory}

In the late 1970s, Skopos Theory, referring to an important functionalist theory of translation, was originated in Germany. It demonstrates "a general shift from predominantly linguistic and rather formal translation theory to a more functionally and socioculturally oriented concept of translation" (Baker, 2004, p. 235). Skopos Theory, being regarded as the core concept of German Functionalism, has offered a new perspective and theoretical basis for the translation of corporate profiles. It has been regarded as a breakthrough and an important supplement to traditional translation ideas. There are three rules of Skopos Theory which we should know. The first rule which all translation activities should follow is Skopos rule. "A translation action is determined by its Skopos; that is, the end justifies the means" (Nord, 2001, p. 29). When the translator is given a context, he should make clearly the specific translation purpose. The second is Coherence rule. It means the

WANG Yin, senior student, English Department, Ningbo Dahongying University, under the guidance of Supervisor HE Ying. 
continuity of translated text should be in line with the target culture and communication context, which will be accepted by receivers. The third is Fidelity rule, which roughly means the translation text should be faithful to the source text.

From the perspective of Skopos Theory, the aim of C-E translation of apparel company profiles is to ensure the target readers' accurate and deep understanding of Chinese companies concerned in order to achieve the desired publicity effect and appeal to their desire to consume. As Nord puts it, "the prime principle determining any translation process is the purpose (Skopos) of the overall translational action" (Nord, 2001, p. 27). Therefore, the translator should bear particular translation principles in mind, which will be adopted in order to achieve the Skopos. The purpose of the C-E translation of company profiles is to attract the target readers' attention so as to promote a desired trade cooperation. A well-translated corporate profile can improve a good corporate image as well as the popularity and competitiveness of its products. However, the English versions are not so satisfactory due to a number of linguistic and cultural translation errors of the target text. It is good for translators to choose the appropriate translation strategies according to the Skopos Theory, such as addition, deletion, adaptation, etc.

\section{Translation Problems in C-E Translation of Apparel Company Profiles}

Observing the small and medium sized apparel company profiles collected by the author, the fact that many English versions of Chinese apparel company profiles are Chinese-based translations will be found. Some translators do not understand the different language features between Chinese and English. Thus, in this part, the author tries to analyze the translation problems and tries to explore the causes of these errors and provide feasible solutions accordingly.

\section{Translation Problems in Linguistic Expressions}

As far as the C-E translation of small and medium sized apparel company profiles are concerned, the most basic problems and errors commonly result from the ignorance of linguistic expressions, which can be mainly demonstrated from two aspects: lexical, syntactical levels.

(1) At lexical level.

Sample A1: 公司主要生产女式时装及珠片时装，如连衣裙、T恤、短裙、夹克、风衣等。

English version: We mainly produce ladies' fashion and embroidered fashion garments, such as dress, T-shirt, short-skirt, jacket and dust coat, etc.

Suggested version: We are specialized in ladies' fashion and embroidered fashion garments such as dresses, T-shirts, short-skirts, jackets, coats, etc. (Hangzhou Yonggao Fashion Garments Co., Ltd.)

Sample A2: 拥有自营进出口权的企业。

English version: with self-managed import \& export right.

Suggested version: The company owns rights of import-export operations. (Zhejiang Tianbo Garments Co., Ltd.)

Sample A3: 根据客户要求订制订量生产祄衫。

English version: Design and produce shirts; Customize shirts according to requests.

Suggested version: Offer customized products. (Yiwu Wenxing Garments Co., Ltd.)

From the Chinese version of Sample A1, we can see that “......主要生产, 主营” is widely used at the beginning of Chinese apparel corporate profiles. Thanks to its popularity, the author finds it tend to be translated into "be engaged in" or "be specialized in". However, many companies use literal approach to 
translate it into "mainly produce", which is lack of professionalism. In addition, from the English version of Sample A2 and A3, the author finds the phenomenon of bad translation of conventional terms for the lack of knowledge on terminologies. As a trade terminology, “自营进出口权” can be translated into "rights of import-export operations” and “根据客户要求订制产品” can be translated into “offer customized products”.

(2) At syntactical level.

Sample A4: 天亚以“爱与支持”的企业文化为核心，凝聚了一大批忠诚、求实、创新型的人才。

English version: With "LOVE \& SUPPORT" as its culture core, Tianya attracts many faithful, practical and innovative talents.

Suggested version: With "LOVE \& SUPPORT" as its culture core, Tianya has attracted numbers of faithful, practical and innovative talents. (Ningbo Tianya Garments Co., Ltd.)

Sample A5: 业务遍及国内大小城市, 产品远销欧美、南美、东南亚、中东、非洲等各地区。

English version: Our business covers both China and abroad. The products have been exported to Europe, North America, South America, Southeast Asia, Middle East, Africa and other regions.

Suggested version: The products of our company are much in demand on the market in China and across the world. (Yiwu Wenxing Garments Co., Ltd.)

In the English version of Sample A4, the author finds a tense error, the sentence should use the present perfect tense because the state has been completed, and has an impact on the future. From the English version of Sample A5, "Europe, North America, South America, Southeast Asia, Middle East, Africa and other regions" can be simply replaced by "on the market in China and across the world", which is easier to understand. Moreover, the concise translation of corporate profiles is attracted a lot by target customers.

\section{Translation Problems in Culture}

Cultural differences are another major factor leading to poor translation in C-E translation of small and medium apparel company profiles. Some Chinese company profiles feature with plenty of idioms and poems, which give customers a deep impression. However, it is difficult for translators to translate idiomatic expressions. So, the translators always use word-for-word method to deal with the culture barrier, which leads to a poor translation of company profiles.

Sample A6: 杭州永高时装有限公司成立于1996年, 工厂位于杭州余杭乔司镇良熟村, 占地3500平方米, 交通 便利。经过 10 多年的不解追求和努力, 公司已发展成为一家颇具规模, 配套齐全的专业女式时装生产厂家。

English version: Hangzhou Yonggao Fashion Garments Co., Ltd. was established in 1996 which is located in Qiaosi Village, Yuhang District, Hangzhou, China. The factory has an area over 3,500 square meters with convenient transportation. After more than 10 years' continuous pursuit and endeavor, it has become a professional manufacturer of ladies' fashion garments with large scale and complete facilities.

Suggested version: Founded in1996, Hangzhou Yonggao Fashion Garments Co., Ltd. is a well-equipped professional manufacturer of ladies' fashion garments. It covers an area of 3,500 square meters with convenient transportation. (Hangzhou Yonggao Fashion Garments Co., Ltd.)

Sample A7: “创新求变, 追求个性” 是我厂一直以来的产品设计理念。“重质量, 重货期, 守信用”是我们的服 务宗旨。

English version: "Seeking Innovation and Pursuit of Personality" is always our designing principle. "Emphasizing on the quality and delivery, keeping the high credence" is our service aim.

Suggested version: Hangzhou Yonggao Group, taking "Innovation for personality" as its product design philosophy and "high quality, delivery on time and keeping faith" as its service tenet. (Hangzhou Yonggao Fashion Garments Co., Ltd.) 
Sample A8: 宁腾牌系列毛衫以其款式新颖、配色亮丽、质地柔和、档次高而闻名于全国羊毛衫行业, 其产销 利在全国同行业中名列前茅。公司拥有自营进出口权, 目前产品在畅销国内的同时, 远销日本、美国、法国、澳 大利亚、欧共体等20多个国家和地区.

English version: The company enjoys a high reputation and leads top sales volume in domestic branch for its products are fashion designed, light colored, softly felt and highly graded. Meanwhile, Ningteng-branded cardigans are received well popularity in over 20 overseas countries and areas such as Japan, the USA, France, Australia and the EN.

Suggested version: We are a leading enterprise in sweater business for our products with high quality and special design. Our company owns rights of import-export operations and products are sold well both at home and abroad. (Ningbo Ningteng Group Co., Ltd.)

Sample A9: 公司建立了从纺纱织布到成衣的一条龙生产线。

English version: The company has established a vertical operation from spinning yarns to finished garments.

Suggested version: The company has established a coordinated process of production line from spinning yarns to finished garments. (Ningbo Yachu Garments Co., Ltd.)

From the English version of Sample A6, it is a common phenomenon that translators always use word-for-word translation to translate the Chinese small and medium sized apparel corporate profiles, which results in redundant words appearing in the C-E translation of company profiles. When introducing the company's basic information in Sample A6, many translators put the company's address in the first place. However, target readers are not interested in the specific address of company, so this part could be neglected. In addition, the main idea of a sentence should be translated first. In Sample A8, "in over 20 overseas countries and areas such as Japan, the USA, Franc, Australia and the EN" could be appropriately replaced by "both at home and abroad" with similar meaning. It is true that the translation of Chinese corporate profiles should be brief and concise; otherwise target readers will be difficulties in understanding the administrative division in China. As for a technical terminology, “设计理念” and “服务宗旨” in Sample A7 could be translated into “design philosophy” and “service tenet”. “自营进出口权” in Sample A8 can be translated into “rights of import-export operations". The author suggests that the translator should accumulate some right translation of terminology. Besides, Chinese company profiles are full of magnificent four-word modifiers and official jargon like “创新求变, 追求个性” in Sample A7 and “款式新颖、配色亮丽、质地柔和、档次高” in Sample A8, translators need to catch the main information rather than use word for word translation and translate them into the target text which the target readers can understand. It is also in line with the principle of teleological purpose. In Sample A9, "Dragon" is a propitious sign welcomed by Chinese people but in foreign countries it is hardly accepted by target readers. So, it is necessary for translators to take cultural differences into consideration when translating this kind of phrases. In this thesis, according to the Skopos Theory, “一条龙” should be translated into "a coordinated process".

\section{Solutions to Problems in C-E Translation of Apparel Company Profiles}

\section{The Conclusion of Translation Strategies}

By analyzing the above cases, the author can draw a conclusion that the linguistic expressions and culture are the key problems which mainly lead to the poor translation of Chinese small and medium sized clothing company profiles. According to the Skopos Theory, here are some translation strategies:

(1) Delete the useless information;

(2) Use concise and accurate words to express the information;

(3) Learn to adjust the structure of the sentence properly; 
(4) Accumulate some English expression of conventional terms;

(5) Choose the appropriate translation strategies according to the Skopos Theory, such as addition, deletion, adaptation, etc.

\section{The Accumulation of Common Expression}

The author has collected and summarized some common expression of C-E translation of small and medium apparel company profiles.

(1) Common vocabulary.

$\begin{array}{llll}\text { Accessory 辅料 } & \text { Acrylic 腈纶 } & \text { Antistatic finish 防静电处理 } & \text { Apparel 成衣 } \\ \text { Appealing look 吸引人的外表 } & \text { Binding 包边 } & \text { Blouse 女装衬衫 } & \text { Bottoms 下装 } \\ \text { Braid 织锦, 织带 } & \text { Bulk production 大量生产 } & \text { Button 钮扣 } & \text { Chemise 宽松服装 } \\ \text { Chic 时髦的, 流行的 } & \text { Classic look 经典款式 } & \text { Leisure style 休闲款式 } & \text { Excellent style 漂亮的款式 } \\ \text { Classification 分类 } & \text { Coating 外套大衣 } & \text { Close fitting 贴身 } & \text { Collar 领子 } \\ \text { Collection 系列 } & \text { Color shading 色差 } & \text { Constructed specification 结构细节 }\end{array}$

(2) Idiomatic expressions

企业精神 Enterprise value

发展历程 History 人才管理 Talents management

直属员工 Affiliated employees/workers

品牌建设 Construction of brand-name

以顾客为导向 With orientation for clients

中国驰名商标 Chinese well-known Mark

“质量第一，信誉至上” High quality, top sincerity

“最高/多..........to the maximum/minimum

独特的综合优势 An unique comprehensive advantage

\section{Conclusion}

In summary, the purpose of the C-E translation of Corporate Profiles is to convey information, establish good corporate images, and stimulate the demand of products. According to Skopos Theory, the action of translation depends on its Skopos, which means the purpose of translation determines the translation strategies and methods that are to be taken aiming to produce an intended target. Therefore, in the C-E translation of the Chinese small and medium sized apparel corporate profiles, translators should adhere to Skopos Theory of the three principles and it is applicable for them to adopt a reader-centered translation strategy. However, from the analysis of apparel corporate profiles, the author finds linguistic and cultural problems still exist, which affects the quality of translation. As for translators, they need to deeply understand the importance of Skopos Theory in translation and accumulate common expression, it is better for them to rearrange the structure, language, and textual level in line with an international audience, linguistic habits, and the text features of English introduction. In addition, the thesis justifies that appropriate addition, deletion, and adaptation and so forth are needed in order to have high-quality company profiles. As for company, more interaction should be promoted. For example, the company should explain the professional knowledge in their field to the translator which is beyond their understanding. Finally, the author hopes that the mistakes pointed out and strategies proposed in this thesis would be of some value to the C-E translation of Chinese small and medium sized apparel corporate profiles as well as other translation texts.

\section{References}

Baker, M. (2004). Routledge encyclopedia of translation studies. Shanghai: Shanghai Foreign Language Education Press. 
LI, D. (2012). Analysis of Chinese profile translation-From the perspective of functionalist approaches. Hubei: Yangtze University.

LI, S. (2015). On English translation of company brochure from the perspective of Skopos Theory with Xiamen Tea Co's brochure as example. Fujian: Fujian Normal University.

LIU, Y. M. (2013). Problems and their solutions in C-E translation of food company profiles in China. Hunan: Central South University.

Nord, C. (2001). Translating as a purposeful activity: Functional approaches explained. Shanghai: Shanghai Foreign Language Education Press.

XIE, L. (2014). On English translation of Henan corporate profiles from the perspective of Skopos Theory. Magazine Official Website, 9, 115-119.

$\mathrm{XU}, \mathrm{H}$. (2015). On the C-E translation of corporate profiles from the perspective of Skopos Theory. Hubei: Foreign Languages Central China Normal University.

YAN, J. X. (2014). On English translation of Chinese corporate profiles from the perspective of Skopos Theory. Overseas English, 178-179.

ZHANG, X. Y. (2012). On English translation of corporate profiles from the perspective of Skopos Theory. Journal Beijing International Studies University, 4, 28-33.

ZHU, S. S. (2014). On English translation of Chinese corporate profiles from the perspective of Skopos Theory. Qingdao: Ocean University of China. 